УДК 811.161.2:[81'37+81'42]

I. Я. Кость

\title{
ЕМОЦЙНИЙ СТАН СТРАХУ ТА ЙОГО ВЕРБАЛІЗАЦІЯ У ПРОЗОВОМУ ТЕКСТІ
}

Кость І. Я. Емоційний стан страху та його вербалізація у прозовому тексті.

Стаття присвячена вивченню вербальної презентації емоційного стану страху в прозовому тексті, виявленню конституентів функціонально-семантичного мікрополя «Страх», їх розподілу за тематичними групами, синонімічними рядами. Окрім номінативних одиниць, були проаналізовані елементи невербального коду емоції.

Ключові слова: функціонально-семантичне мікрополе, прозовий текст, вербалізація, страх. 
Кость И. Я. Эмоциональное состояние страха и его вербализация в прозаическом тексте.

Статья посвящена изучению вербальной презентации эмоционального состояния страха в прозаическом тексте, выявлению конституентов функционально-семантического микрополя «Страх», их распределению по тематическим группам, синонимическим рядам. Кроме номинативных единиц, были проанализированы элементы невербального кода эмоции.

Ключевые слова: функционально-семантическое микрополе, прозаический текст, вербализация, страх.

Kost I. Ya. The emotional state of fear and its verbalization in a prose text.

This article is devoted to the study of verbal presentations of emotional state of fear in a prose text; it reveals the elements of functional-semantic microfield of Fear, their division into thematic groups and synonymous rows. Moreover nominative units it has been analyzed the non-verbal elements of the emotional code.

Key words: functional-semantic microfield, prose text, verbalization, fear.

Емоційний світ особистості надзвичайно багатогранний, неповторний і породжує значний інтерес учених різних галузей знань: психологів, філософів, теологів, лінгвістів. Безумовно, дослідження цієї частини людського внутрішнього світу є захоплююче і пожадане, адже пізнати глибини і таїну незвіданої душі хочеться багатьом. Мовна грань цього психічного феномену стала предметом наукових студій дещо пізніше, проте кількісно та результативно може стати поряд 3 психологічною.

Теоретичні підвалини та практичний досвід вивчення вербальної репрезентації емоцій висвітлені у працях Ю. Д. Апресяна, І. А. Аскерової, Л. Г. Бабенко, О. О. Борисова, А. Вежбицької, С. Г. Воркачова, М. В. Гамзюка, А. А. Залізняк, В. І. Кононенка, М. О. Красавського, Ю. Ф. Прадіда, В. І. Шаховського та ін. Часто лінгвісти фокусують свою увагу на таких почуттях, як кохання, гнів, страх, радість, сум тощо. Основними аспектами дослідження мовного втілення цього феномену $є$ концептуальний, лінгвоконцептуальний, етимологічний, функціональносемантичний. Українські та російські вчені здебільшого досліджують вербалізацію почуття на матеріалі англійської, російської та німецької мов, рідше - української, французької.

Класичний прикладом структурного i семантичного опису фразеологічних одиниць на позначення емоцій є монографія та укладений ідеографічний словник Ю. Ф. Прадіда. Учений здійснив тематичний поділ сталих сполук та зупинився докладніше на емоційних реакціях організму людини, зафіксованих у фраземах. Як зазначає дослідник, почуття страху впливає на органи зору та слуху, функціонування серцево-судинної системи, потовиділення, пропадання голосу, та найхарактернішим симптомом переживання $\epsilon$ тремтіння всіх м'язів тіла [11, с. 99-101].

О. О. Борисов зосереджує свою увагу на дослідженні концептуальносемантичних особливостей номінативних одиниць англійської мови, які вербалізують емоцію страху, мовні одиниці розподіляє за тематичним критерієм на 8 парцел: 1) стан страху, 2) експірієнцер страху, 3) симптом страху, 4) риси характеру, 5) агент, 6) види діяльності, 7) загроза, 8) результати діяльності [3]. I. А. Аскерова здійснює семантичний аналіз лексико-семантичного мікрополя «Страх» на матеріалі польської мови, 
визначає етноспецифічні уявлення народу, кодифіковані в метафоричних структурах, зосереджується також на історико-етимологічному аспекті назв емоційного стану [1].В.І.Кононенко презентує вплив народних вірувань та асоціацій на творення номінативів емоції і фразеологізмів 3 компонентом страх, детально зупиняється на аналізі концепту страх у художньому дискурсі М. Коцюбинського, виявляє зображення емоції як істоти, а також виокремлює нові конотації, якими поповнюється концепт. Учений висновковує, що страх у світосприйнятті письменника зокрема, як i українського народу загалом, наділений негативною оцінкою i сприймається як вияв слабкості особистості [9].

Грунтовне дослідження етимології синонімічного ряду назв емоції страху з лінгвокультурологічним коментарем пропонує М. О. Красавський. Матеріалом студії слугують лексеми російської та німецької мов. Учений здійснює аналіз за трьома параметрами: 1) час появи слова, 2) час зародження лексичного значення з семою «страх», 3) джерело і причина виникнення слова та його емотивного значення [10, с. 128].

Зіставне дослідження емоційного концепту страх як елементу російської та французької мовних картин світу представляє I. О. Волостних. Вивчаються й аналізуються прямі та непрямі номінативи в етимологічному та семантичному аспектах, особлива увага приділяється розгляду метафоризованих словосполучень, до складу яких входять назви емоції [7]. Страх як лінгвокультурний концепт, що презентує особливості російської та німецької психології, є об’єктом студії О. Ю. Бутенко. Мовознавець зупиняється на онтологічних засадах аналізованого концепту в європейській культурі, виокремлює його смисли, акцентує на спільному та етноспецифічному в концептуалізації емоції обома мовами. Важливим результатом дослідження є визначення позитивного ставлення до страху в німецькій лінгвокультурі і негативного - у російській [4].

Концептуальний аспект емоції «страх» був одним із об'єктів дослідження Х. О. Погосової (вербальна репрезентація емоційного концепту в англійській та російській мовних картинах світу), Р. М. Рикунова (аналіз концепту «страх» в англійській мові, виокремлення ядра і шарів концепту емоції, виявив особливості лексичної вербалізації страху в мовленні), І. С. Баженової (особливості мовного позначення емоції в художньому російському і німецькому тексті), Ю. Л. Гончарової (досліджуються семантичний та прагматичний аспекти номінації емоції страх в російській мові, синонімічна та антонімічна парадигми, метафорична сполучуваність), Т. О. Муллінової (функціональносемантичний аспект вербалізації емоції в російській прозі) та ін.

Існування такої чисельної низки досліджень засвідчує не лише той факт, що страх є однією з базових емоцій, а й особливу його вагомість для світогляду людини. 
Незважаючи на те, що цей психічний феномен був об'єктом різноаспектних студій, існує чимало неопрацьованих питань, зокрема виявлення способів об'єктивації емоції в мовленні, в художньому тексті засобами української мови. Це зумовлює актуальність нашого дослідження і його мету - виокремлення засобів вербалізації емоційного стану страху в прозовому тексті. Матеріалом дослідження мовної репрезентації психічного феномену слугували твори Ірини Вільде, зокрема трилогія «Метелики на шпильках» [5] та оповідання [6].

Досягнення поставленої мети передбачає реалізацію таких завдань: 1) представити вербальні засоби номінації емоції як складові функціонально-семантичного мікрополя, виокремивши ядро та периферію, синонімічні ряди, тематичні групи і ряди лексично паралельних слів; 2) розглянути синтагматичні відношення номінативів, зокрема мовне втілення категорії інтенсивності переживання страху.

Мовні засоби, що маніфестують емоції, формують функціональносемантичне поле «Емоційні стани», однією із складових якого $є$ мікрополе «Страх». В аналізованих нами творах Ірини Вільде страх $є$ одним 3 домінуючих почуттів, поряд з радістю та любов’ю.

Мікрополе «Страх» творять такі конституенти: 1) 221 лексична одиниця, серед яких превалюють дієслова, 2) 7 фразеологізмів, 3) 19 образних конструкцій, 4) 52 дескриптивні елементи, з них 34 власне дескриптивні та 18 номінативно-дескриптивні. Ядро мікрополя формують слова боятися та страх, ближню периферію - страшний.

Лексеми, які вербалізують емоцію страху, презентовані синонімічними рядами: 1) страх (32 слововживання), острах (8), перестрах (5), переляк (2), жах (2), переполох (1), тремтіння (1), трепет (1); 2) боятися (59), лякатися (5), перелякатися (5), настрашитися (5), злякатися (4), побоятися (3), тремтіти (3), перестрашитися (2), перелякуватися (1), налякатися (1), жсахатися (1), завмирати (1); 3) лякати (5), сполошити (3), страшити (2), злякати (1), налякати (1), перелякати (1), жахнути (1); 4) страшний (18), жахливий (2), кошмарний (2), перестрашений (1), грізний (1), жаский (1), лиховісний (1); 5) боязкий (2), полохливий (1), сполоханий (1); 6) переляканий (13), перестрашений (7), зляканий (2), наляканий (1); 7) страшно (4), злякано (2), моторошно (2), перелякано (2), сполохано (1), боязко (1). Використані Іриною Вільде слова концентруються в ряди лексично паралельних слів (термін використаний вслід за Н. Ф. Сжовою [8, с. 11]), які складаються з різної кількості одиниць (від 15 до 1): 1) переляк, лякатися, злякатися, перелякуватися, перелякатися, налякатися, лякати, злякати, налякати, перелякати, переляканий, зляканий, наляканий, перелякано, злякано; 2) страх, острах, перестрах, настрашитися, страшити, перестрашитися, страшний, перестрашений, страшно; 3) переполох, полохливий, сполошити, сполоханий, сполохано; 
4) жах, жахатися, жахнути, жахливий; 5) боятися, побоятися, боязкий; 6) тремтіння, тремтіти; 7) кошмарний; 8) жаский; 9) лиховісний; 10) трепет; 11) грізний.

Використовуючи класифікацію Л. Г. Бабенко [2], номінативи страху групуємо в такі тематичні групи: 1) емоційний стан (страх, острах, перестрах, перестрашений, страшно, переляк, лякатися, переляканий, зляканий, наляканий, перелякано, злякано, переполох, сполохано, жах, жахатися, боятися, побоятися, тремтіння, тремтіти, трепет), 2) становлення емоційного стану (настрашитися, перестрашитися, злякатися, перелякуватися, перелякатися, налякатися), 3) емоційний вплив (страшити, страшний, лякати, злякати, налякати, перелякати, сполошити, жахнути, жахливий, жаский, кочмарний, лиховісний, грізний), 4) емоційна характеристика (полохливий, боязкий, сполоханий). Групу зовнішнього вияву емоції розглядаємо зосібна, оскільки ії конституенти виконують здебільшого функцію дескрипції, рідше - поєднують ії з номінацією.

Іменникова репрезентація емоційного стану реалізовується лексемами страх, острах, перестрах, переляк, переполох, жах, які вживає письменниця у прямому значенні, та тремтіння, трепет - у переносному. Окрім кількісно різного представлення в текстах, ці слова різняться ще й якісно. Так, іменник жах, на відміну від усіх інших, вказує ще й на інтенсивність переживання почуття, що зафіксовано у лексичному значенні («Почуття, стан дуже великого переляку, страху, що охоплює кого-небудь» [13, II, с. 513]): Пересторога, щось більще, як пересторога, погроза, жах вихоплюється з ї̈ задиханих грудей [5, с. 290]. Решта слів вербалізують «1. Стан хвилювання, тривоги, неспокою, що викликаний очікуванням чого-небудь неприємного, небажаного» [13, IX, с. 753]: Ї̈̈ лице набрало такого зосередженого виразу, щчо Забейко відчув щесь наче страх перед дочкою [6, с. 87]; Ціла ж класа тремтить, і їі трепет - це тільки рух малого колішатка в загальному механізмі [5, с. 162].

Для вербалізації емоційного стану та його становлення Ірина Вільде використовує дієслова боятися, побоятися, лякатися, злякатися, налякатися, перелякуватися, перелякатися, перестрашитися, настрашитися із значенням «Відчувати страх перед ким-, чим-небудь» [13, I, с. 225]: Марія боӥться чогось іншого в июю хвилину... [6, с. 388]. Вторинна номінація представлена одиницями тремтіти і завмирати: Стежечками, стежечками і мама заходить аж до Дарчиного сорому. Дарка завмирає [5, с. 106]. Про відчуття сильного переживання сигналізує лексема жахатися («1. Відчувати жах перед ким-, чим-небудь; дуже лякатися кого, чого-небудь» [13, II, с. 513]): Я хіба здурію від иьього всього. Хіба зроблю собі щось...»- жсахається сама себе [5, с. 250].

Дієслова лякати, злякати, налякати, перелякати, страшити, настрашити, сполошити маніфестують емоційний вплив на людину i 
мають значення «Викликати переляк, страх; злякати» [13, V, с. 123]: I знову було все так по-давньому, щь Дарка мусіла аж нишком запитати себе, чи це той сам вуйко, щзо вполудне так налякав ї? [5, с. 65]. Окрім вказівки на породження емоції, лексема жахнути конкретизує силу переживання («Однокор. до жахати 1» [13, II, с. 514], жахати 1 - «Викликати жах у кого-небудь; дуже лякати когось» [13, II, с. 513]): В канцелярії панував балаган, який мене жсахнув [6, с. 110].

Емоційний вплив маніфестується також прикметниками страшний («Який своїм змістом, своєю суття викликає, вселяє почуття страху» [13, IX, с. 760]), жахливий («Який викликає почуття жаху; страшний, страхітливий» [13, II, с. 514]), кошмарний («Сповнений кошмарів; жахливий» [13, IV, с. 317]), лиховісний («Який викликає страх, тривогу» [13, IV, с. 497]), грізний («2. Який викликає, навіває страх» [13, II, с. 170]): Влетіла, кинула цүю кошмарну вістку $і$ вилетіла, а Дарцуі аж віддих спинило [5, с. 152]; I знову ияя лиховісна, мертвецьька тиша [5, с. 288].

Лексикалізація емоційної характеристики здійснюється за допомогою прикметників боязкий, полохливий, сполоханий у значенні «Пройнятий страхом» [13, I, с. 224; VII, с. 99], «2. Який виражає страх, переляк, тривогу» [13, XI, с. 567]: Дарка дивиться на изього відважного, рудого хлопчиська, і нова, полохлива думка назріває в ї̈ мозку [5, с. 292].

Дієприкметникова маніфестація переживання представлена лексемами зляканий, переляканий, наляканий, перестрашений: Зсувається на долівку і так, напівлежачи, скулена, злякана, читає листа [6, с. 54].

Прислівникова номінація емоції страху послуговується одиницями страшно, моторошно, сполохано і боязко у значенні «Хто-небудь відчуває страх, боязнь» [13, IX, с. 760]: Та ледве дійила до закруту коло ичеркви, стало їи так страшно від того, щзо вона наробила, щзо хотіла вже звернути на пошту й на чому світ прохати урядовия, щуоб віддав ій ту листівку [5, с. 20]; Такий близенький до дійсності сон, аж моторошно [5, с. 323].

Письменниця частково залучає засоби фразеологічного пласту мови. Емоційний стан об'єктивується фраземами мати страх, мати дивний острах під шкірою, попід шкірою пробігає жаске вражіння (остання фразема побудована за аналогією до попередніх) - «Боятися, побоюватися кого-, чого-небудь» [12, с. 378]: Свідома того, щзо за иибами темніє, $i$ має дивний острах десь під икірою, щуоб тепер не ввійшов хтось у кімнату, де дрімає, і не засвітив світла [6, с. 81]; кидати в жар - «2. Кого-небудь охоплює жах, комусь стає страшно» [12, с. 291]: Порівняння видалось йому таким страшним, щуо його раптово ажс кинуло в жсар [6, с. 33]; страх охоплює - варіант фраземи острах бере (обіймає, охоплює $i$ m. ін.) / узяв (обійняв, охопив $i \mathrm{~m}$. ін.) «Стає неспокійно, страшно і т. ін. комусь» [12, с. 471]: Дарку знову огортає страх [5, с. 289]; нагнати / наганяти 
страху - варіант фразеологізму наганяти (нагонити) / нагнати холоду «Викликати страх, переляк, занепокоєння і т. ін.» [12, с. 417]: Слово изе наганяло стільки страху, щзо його на думку Дарки, можна було б заступити словом «татари! татари!» [5, с. 202].

Власне результатом авторського мовного втілення відчуття емоційного стану $є$ яскраві метафоризовані образи. Конструкції страх заходить з одної, то з другої сторони коло серия; страх, щчо прошумів по ї̈ жилах, збурив кров і неможливе зробив дійсним, знесилив Лесю; задушить страх, мов ангіна; страх ще не поглинув; страх, смертельний, білий страх спалює Дарку на вугілля; страх наздоганяє; жах ішов; страх набирає якогось фосфоричного блиску; страх, щзо блиснув і згас; куций страх, щзо походив від болючої свідомості руху вербалізують сприйняття страху як живої істоти, здатної огортати людину, спалювати на вугілля, поглинати зусилля і знесилювати, ходити, душити, наздоганяти, збурювати кров, отримувати забарвлення: Страх перед чужим селом і людьми заходить 3 одної, то з другої сторони коло Дарчиного серця [5, с. 103]; Це Леся добре розуміла, але страх, що прошумів по ї̈ жсилах, збурив кров $і$ перед хвилиною неможсливе зробив дійсним, знесилив зовсім Лесю [6, с. 106]. У структурах прогуде гураган периого страху; гострі дотики страху; страх доходить до того стану, щзо вона перестає боятись нашарована ще й інформація про інтенсивність переживання: $A$ за порогом цьього негостинного дому знову ніч $i$ знову гострі дотики страху [5, с. 104]. Аналогізація емоційного стану із припиненням життєдіяльності прослідковується в конструкції переставати існувати: Дарка завмирає. Можна сказати: перестас існувати [5, с. 106].

Окрім метафоризованих образів, побудованих на основі використання номінативних засобів емоцій, Ірина Вільде створює барвисті картини душевних переживань засобами без використання назв почуттів. Такі вербальні форми імпліцитної об'єктивації емоційних станів ми умовно називаємо образними конструкціями. Частина 3 них грунтується на виявленні внутрішніх відчуттів людини при переживання емоційного стану - серще підстрибнуло; пробігло щзось жахливе ї̈ нервами: Директор тепер розлютився: гримнув долонею по столі, аж папери на ньому $i$ Дарчине серце в грудях підстрибнули [5, с. 287]. Для образної кодифікації почуття страху Ірина Вільде також послуговується прийомом порівняння емоції з відчуттям людини в певних умовах: "Скільки літ може вона мати?» - знову подумав, і раптом йому здалося, ніби звалилась на нього широка, темна стіна [6, с. 71].

Аналіз синтагматичних відношень елементів мікрополя дозволив виявити низку лексем, що вербалізують градацію сили переживання i/aбо вказують на характер відчуття. Так, слова смертельний, божевільний, смертоносний конкретизують інтенсивність почуття, презентованого іменником страх, наглий - перестрах: Був ц̧е пери за все голий, 
божевільний, смертоносний страх перед самою можливістю чогось, що стало вже дійсністю [6, с. 106]; I той наглий перестрах, що його підпалює ия свідомість, уже хвилиночку згодом переходить у щось дуже тепле й сердечне: якась незбагнута тайна зависла над ними троїма, тайна, щуо звела ї̈ з Стефою і кинула одну одній в обійми [5, с. 208].

Градуювання глибини процесу переживання та емоційного впливу, об'єктивованих дієсловами, здійснюється також через контактне вживання прислівників дуже, менше (боятися); надобре (настрашитися); на добре (перелякатися); так (налякати) і словосполучення по саму горлянку (перелякатися): Дарка на добре перелякалася: Мария готова свій жарт замінити у правду [5, с. 50]; I знову було все так по-давньому, щэо Дарка мусіла аж нишком запитати себе, чи ие той сам вуйко, щзо вполудне так налякав ï? [5, с. 65].

Номінатив перестрашений у різних контекстах може поєднуватися 3 інтенсифікаторими зовсім, дуже, страшенно, такий, які вказують на високий ступінь переживання, а також з деінтенсифікатором трохи лише, що свідчить про незначне відчуття переляку: - А щзодо мене, - злагідніла мама тон, - то я була страшенно здивована й перестрашена, як мені лікар сказав, щзо то ніяка «простуда», а - вагітність у третім місяиі [5, с. 458]; Він не знає і ніколи не дізнається про те, щу у хвилині, коли він горів увесь, вона була холодна, трохи лише перестрашена $і$ не відповідала йому ні одним своїм нервом [5, с. 436].

Індивідуальність авторського світовідчуття яскраво проявляється у словосполученнях, які здійснюють характеристику емоційного стану. Асоціативні епітети білий, голий (страх); холодний, дивний (острах) ілюструють не лише якісну ознаку почуття, а й частково вказують на глибину переживання: Вчула холодний острах у своїм нутрі [5, с. 401].

Мовне оформлення зовнішніх проявів емоцій в аналізованих текстах реалізуються окремими словами, словосполученнями та реченнями. Особливістю вербалізації $є$ наявність чи відсутність семи «переживання» у лексемах та номінативів емоцій у конструкціях, що описують фізіологічні симптоми переживання. Відповідно дескриптивні одиниці поділяємо на 1) власне дескриптивні й 2) номінативно-дескриптивні. В Ірини Вільде простежується тенденція до домінування власне дескриптивних конструкцій у функціонально-семантичному полі «Емоційні стани» загалом та в мікрополі «Страх» зокрема.

Невербальна презентація емоції здійснюється за допомогою фонації, міміки, мануальних рухів та вегетаційних змін. Фонаційна характеристика презентована різними видами проявів з урахуванням градації звучності та якості - криком (скрикує зі страху / злякано; заголосила; зойкнула), вигуком (перелякано вигукнула), шепотом (питає переляканим шепотом), відсутністю мовлення (не могла говорити; мовкне; розтулює уста $i$ проковтує слово; забула в одній хвилині говорити) і нечленороздільною ๑І. Я. Кость, 2011. 
мовою (безладні звуки): У темній «гардеробі» хоче дібратись до ліжка, намацує і скрикує зі страху: - Хто тут!? [5, с. 86]; - Дариюю... Дарию... вона така схвильована чи перелякана, щуо не могла говорити. Слова заломлювалися їй десь у горлі і виходили, як безладні звуки [5, с. 318].

До арсеналу мімічних проявів входять характеристика виразу обличчя загалом (думка мусіла острахом віддзеркалюватись на обличчі, обличчя боязке, перестрашений вираз обличчя) та певних частин лиця, зокрема, очей (перелякані, перестрашені, боязкі, сполохані, залякані очі; iз страхом подивитися; затроєні страхом очі; очі мають трохи завеликий білий обруч навколо дугівки), брів (піднесені вгору брови), губів (опущцені кутики уст; кусала собі губи): Не слід робити таких перестрашених очей... [6, с. 108]; Дарка бачить з його піднесених вгору, як дві кочергочки, брів і опущених кутиків уст, щуо він побоюється за Дарчин розум [5, с. 271]. Ще одним виявом страху є сльози: Орисьці стають сльози в ouax [5, с. 101].

Мануальний вияв емоції презентований жестом закривати лище долонями, що на підсвідомому рівні сприймається як втеча від тієї реальності, яка спричиняє відчуття страху, та втратою контролю над пальцями рук: - Рятуй нас, Мати Божа, - заголосила Ориська $і$ закрила лице долонями [5, с. 204]; Звук изїі малої потвори так подіяв на Дарку, щуо вона від страху втратила контроль над своӥми пальцями [5, с. 204].

Емоція страху спричиняє такі вегетативні зміни в організмі людини, як тремтіння (стрепенулась; здригнувся; здригається, наче від електричного струму; труситись), зміна пігментації обличчя (зблідла, приблідла, поблідлий, кров втекла з обличчя, з червоними плямами на лиці), порушення функціонування дихальної системи (задихана; відчув, щзо забракло повітря; віддих спинило), посилене потовиділення (впріла зі страху, щзось тепле з-під пах котиться, піт обілляв, теплі краплини поту скапують з виска), відчуття холоду (якби хто снігу поза сорочку насипав): Аж тепер звільняють ї̈ кліші його рамен, $i$ вона прожогом влітає до вітальні, $з$ червоними плямами на лиці, задихана, перелякана $i$ переможена [5, с. 88]; Стіна була легка, не здушила його, але відчув, шьо забракло йому повітря і світла [6, с. 71]; Даризі в першій хвилині якби хто снігу поза сорочку насипав: “Ой, Боже, істерія в тата чи що?» [5, с. 430].

Невербальним покажчиком емоційного переживання є також постава людини (скулена) та іiі рухи (мчить, здеревіла зо страху, перелякано кинулась обіруч, сполохано иусьнула чимсь під капу): Зсувається на долівку і так, напівлежачи, скулена, злякана, читає листа [6, с. 54]; Чи мусіла так шапко, можна сказати, перелякано кинутись обіруч до Зої? [5, с. 371].

Отже, вербалізація страху здійснюється 299 мовними одиницями, серед яких номінативних - 247 і дескриптивних - 52. Для номінації 
емоційного стану письменниця послуговується 221 лексемою, здебільшого дієсловами, 7 фразеологізмами і 19 образними назвами. Ядром мікрополя є слово боятися, ближню периферію формують страх, страшний, інші - це дальня периферія. Лексеми, що маніфестують емоційний стан, вживаються у прямому значенні, за винятком тремтіння, трепет, тремтіти, що ілюструють переносне значення, і завмирати - контекстуальне. Широко представлений невербальний код емоційного стану, особливо вегетативні зміни, фонація та міміка. У дескриптивних одиницях спостерігається превалювання власне дескриптивних конструкцій над номінативнодескриптивними у співвідношенні 2:1. У подальшому логічним видається дослідження вербального представлення емоційного стану страху в інших художніх творах і виявлення специфіки мовного втілення психічного феномену в різножанрових текстових полотнах та в інтерпретації переживання різними митцями слова.

\section{Література}

1. Аскерова I. А. Семантичне поле назв емоційно-афективних станів у польській мові : автореф. дис. на здобуття наук. ступеня канд. філол. наук : спец. 10.02.03 «Слов'янські мови» / І. А. Аскерова. - К., 2006. $-19 \mathrm{c}$.

2. Бабенко Л. Г. Лексические средства обозначения эмоций в русском языке / Л. Г. Бабенко.Свердловск : Из-во Урал. ун-та, 1989.- 184 с.

3. Борисов О. О. Мовні засоби вираження емоційного концепту страх : лінгвокогнітивний аспект (на матеріалі сучасної англомовної художньої прози) : автореф. дис. на здобуття наук. ступеня канд. філол. наук : спец. 10.02.04 «Германські мови» / О. О. Борисов. - Донецьк, 2005. - 20 с.

4. Бутенко Е. Ю. Концептуализация понятия «страх» в немецкой и русской лингвокультурах : автореф. дис. на соискание уч. степени канд. филол. наук : спец. 10.02.20 «Сравн.-истор., типологич. и сопостав. языкознание» / Е. Ю. Бутенко. - Тверь, 2006. - 15 с.

5. Вільде І. Метелики на шпильках. Б’є восьма. Повнолітні діти : [повісті] / Ірина Вільде. - Дрогобич: Видавнича фірма «Відродження», 2007. - 488 с.

6. Вільде I. Троянди і терня : [повісті та оповідання] / Ірина Вільде. - К. : Держлітвидав України, 1961. $-354 \mathrm{c}$.

7. Волостных И. А. Эмоциональные концепты «страх» и «печаль» в русской и французской языковых картинах мира : лингвокультурологический аспект : автореф. дис. на соискание уч. степени канд. филол. наук : спец. 10.02.19 «Теория языка» / И. А. Волостных. - Краснодар, 2007. - 21 с.

8. Ежова Н. Ф. Способы языковой репрезентации эмоциональных концептов в романе Л.Н.Толстого «Анна Каренина» : автореф. дис. на соискание уч. степени канд. филол. наук : спец. 10.02 .01 «Русский язык» / Н. Ф. Ежова. - Воронеж, 2002. - 24 с.

9. Кононенко В. Концепти українського дискурсу : [монографія] / Віталій Кононенко. - К. - ІваноФранківськ : Плай, 2004. - 248 с.

10. Красавский Н. А. Эмоциональные концепты в немецкой и русской лингвокультурах : [монография] / Н. А. Красавский. - Волгоград : Перемена, 2001. - 495 с.

11. Прадід .. Ф. Фразеологічна ідеографія (проблематика досліджень) / Ю. Ф. Прадід. Сімферополь, 1997. - 252 с.

12. Словник фразеологізмів української мови / [уклад. В. М. Білоноженко та ін.]. - К. : Наукова думка, 2008. - 1104 с. - (Словники України).

13. Словник української мови : в 11 т. / [ред. колег. І. К. Білодід (голова) та ін.]. - К. : Наукова думка, 1970-1980. 